\title{
Atlas of the amphibians and reptiles of northern Morocco: updated distribution and patterns of habitat selection
}

\author{
Mohamed Mediani1 ${ }^{1, *}$, José Carlos Brito ${ }^{2,3}$, Soumia Fahd ${ }^{1}$ \\ ${ }^{1}$ Laboratoire "Ecologie, Biodiversité et Environnement", Faculté des Sciences de Tétouan, Université Abdel- \\ malek Essaâdi, M’Hannech, BP 2121, Tétouan, Morocco. \\ ${ }^{2}$ CIBIO/InBIO, Centro de Investigação em Biodiversidade e Recursos Genéticos da Universidade do Porto, \\ Campus Agrário de Vairão, R. Padre Armando Quintas, 4485-661 Vairão, Portugal. \\ 3 Departamento de Biologia da Faculdade de Ciências da Universidade do Porto, Rua Campo Alegre, 4169- \\ 007 Porto, Portugal. \\ *Correspondence: Laboratoire "Ecologie, Biodiversité et Environnement", Faculté des Sciences de \\ Tétouan, Université Abdelmalek Essaâdi, M'Hannech, BP 2121, Tétouan, Morocco. Phone: \\ +212672126805, E-mail: mediamed05@yahoo.fr
}

Received: 27 October 2014; returned for review: 3 December 2014; accepted: 21 July 2015.

Observational data collected from bibliography and during herpetological surveys in northern Morocco between 1989 and 2014 were plotted to generate updated distribution maps of amphibians and reptiles using a UTM $5 \times 5 \mathrm{~km}$ grid system. Eleven amphibians and 53 reptiles were observed, including three amphibians and nine reptiles endemic to Morocco. In both taxonomic groups, three distinct species categories were identified in the area: widely distributed species, species restricted to particular environmental characteristics, and species with small and / or fragmented distributions. For total species richness, 10 areas of high diversity were identified. These areas were common to all taxonomic groups and correspond roughly to Mediterranean-type habitats. Amphibians constitute a relatively homogeneous group according to their habitat selection patterns while reptiles can be grouped in three assemblages: 1) generalist species with broad distributions in northern Morocco; 2) species occupying Mediterranean environments, generally abundant in the north-western region; and 3) species that occupy arid habitats, frequently found in the eastern region. The topographic complexity of northern Morocco apparently creates microenvironmental conditions for each group and is related to high levels of species diversity observed: $78 \%$ and $52 \%$ of the total number of amphibians and reptiles of Morocco, respectively. These findings strengthen the status of northern Morocco as a priority area for herpetofauna conservation at the national level.

Key words: conservation; habitat selection; herpetofauna; priority a rea; species richness.

Atlas de los anfibios y reptiles del norte de Marruecos: actualización de la distribución y los patrones de selección de hábitat. Recopilamos datos observaciones obtenidos tanto de la literatura como de muestreos herpetológicos realizados en el norte de Marruecos entre 1989 y 2014 para generar mapas de distribución actualizados, empleando una cuadrícula UTM de $5 \times 5 \mathrm{~km}$, de las especies de anfibios y reptiles. Observamos 11 anfibios y 53 reptiles, incluyendo tres especies de anfibios y nueve de reptiles endémicos de Marruecos. Para ambos grupos taxonómicos identificamos tres tipos de especies en la zona: especies de amplia distribución, especies restringidas a unas 
condiciones ambientales particulares, y especies con áreas de distribución pequeñas y / o fragmentadas. Para la riqueza total de especies identificamos 10 áreas de elevada diversidad, las cuales fueron comunes a todos los grupos taxonómicos y correspondieron generalmente a ambientes mediterráneos. Los anfibios constituyen un grupo homogéneo de acuerdo a la selección de su hábitat, mientras que los reptiles se pueden agrupar en tres tipos: 1) especies generalistas de amplia distribución en Marruecos; 2) especies presentes en ambientes mediterráneos, generalmente abundantes en la región noroccidental; y 3) especies que ocupan ambientes áridos y que aparecen frecuentemente en la región oriental. La compleja topografía del norte de Marruecos parece crear condiciones micro-ambientales para cada grupo y está en relación con la elevada diversidad observada, que abarca respectivamente el 78\% y el 52\% del número total de especies de anfibios y reptiles presentes en Marruecos. Estos hallazgos refuerzan la importancia del norte de Marruecos como un área prioritaria para la conservación de la herpetofauna a nivel nacional.

Key words: áreas prioritarias; conservación; herpetofauna; riqueza de especies; selección de hábitat.

Atlas des amphibiens et reptiles du nord du Maroc: actualisation de la distribution et les patrons de sélection de l'habitat. Les données d'observation recueillies de la bibliographie et lors de prospections herpétologiques réalisées dans le nord du Maroc entre 1989 et 2014, nous ont permis d'actualiser les cartes de distribution des amphibiens et des reptiles de cette région en utilisant un système de grille UTM $5 \times 5 \mathrm{~km}$. Onze amphibiens et 53 reptiles ont été observés, dont trois et neuf endémiques marocains, respectivement. Pour les deux groupes taxonomiques, trois catégories distinctes ont été identifiées dans la région: les espèces largement répandues, les espèces inféodées à des caractéristiques environnementales particulières et celles à distribution réduite et / ou fragmentées. Concernant la richesse en espèces, 10 zones de grande diversité ont été identifiées. Ces zones sont communes à tous les groupes taxonomiques et correspondent en général aux habitats de type méditerranéen. Selon leurs modèles de sélection des habitats, les amphibiens forment un groupe relativement homogène, tandis que les reptiles forment trois groupes distincts: 1) les espèces généralistes, présentant une ample répartition au nord du Maroc; 2) les espèces occupant les milieux méditerranéens; généralement abondantes dans les régions du nordouest, et 3) les espèces qui occupant les habitats arides, fréquents dans l'Oriental. La complexité orographique $\mathrm{du}$ nord marocain crée apparemment des conditions micro-environnementales pour chaque groupe et est liée à l'importante diversité spécifique observée: $78 \%$ et $52 \%$ du nombre total des amphibiens et des reptiles du Maroc, respectivement. Ces résultats renforcent le statut du nord du Maroc en tant que zone prioritaire pour la conservation de l'herpétofaune au niveau national.

Key words: conservation; herpétofaune; richesse spécifique; sélection d'habitat; zone prioritaire.

Northern Morocco is located in the Mediterranean Basin hotspot, one of 34 global areas simultaneously gathering high biodiversity and high levels of threat (Myers et al., 2000; Mittermeier et al., 2004). Northern Morocco also concentrates a large portion of the terrestrial biodiversity in the Mediterranean Basin and amphibians and reptiles constitute a major component of such diversity, especially in the western Mediterranean and north Africa (Bons \& Geniez, 1996; Schleich et al., 
1996; Geniez et al., 2004). The region is also characterised by a high proportion of endemic species (SChleich et al., 1996; MaRTínez-Freiría et al., 2013) and by the presence of relict elements of Palearctic fauna (Bons \& Geniez, 1996). The high richness in northern Morocco has been associated with the presence of Rif and Atlas Mountains, which divide the country into several bioclimatic regions of Mediterranean type (MÉDAIL \& QuÉzeL, 1999), characterised by hot and dry summers and cold and wet winters. The prevailing conditions allow for distinguishing at least three climatic regions: an Atlantic climate attenuated by moisture from the ocean in the western area, a mountain climate in the main summits, and a continental climate, more or less arid, inland and in the Oriental region (Sobrino \& Raissouni, 2000). This geographical diversity also allowed the allopatric speciation of several species (e.g. Brown et al., 2002; Fritz et al., 2005; Recuero et al., 2007). Moreover, phylogenetic analyses over the past decade have identified a large number of genetic lineages within Moroccan herpetofauna, sometimes leading to the description of several new species or species complexes (e.g. Harris et al., 2003; Perera et al., 2007; Carranza et al., 2008; Pinho et al., 2008; Fonseca et al., 2008, 2009; Velo-Antón et al., 2012).

Atlases of species distribution are essential sources of data to evaluate largescale patterns of species geographical ranges and changes in their distribution in space and time (Sillero et al., 2005). These atlases can also be used, among other subjects, for clarifying the spatial distribution of species and determining the geography of population distribution, documenting and analysing changes in population size and range, providing framework data for survey designs, evaluating habitats occupied by species and communities, and for ecological modelling of species distribution (e.g. Anderson et al., 2002; Hirzel et $a l ., 2002)$. The most frequently used system in biodiversity distribution atlases in the Western Mediterranean is based on the UTM (Universal Transverse Mercator) coordinate system, and it has been used in many cases in the Iberian Peninsula (e.g. Pleguezuelos et al., 2002; Ayllón et al., 2002-2003; Sillero et al., 2005; SoAres et al., 2005) and Morocco (e.g. Fahd \& Pleguezuelos, 1996, 2001; Belqat \& Adler, 2001; Bennas et al., 2001; El Haissoufi et al., 2010).

A distribution atlas of the herpetofauna of Morocco was published in the mid1990s (Bons \& Geniez, 1996), and there have also been some publications focusing on partial regions of the country, such as the Rif's mountains (Fahd \& Pleguezuelos, 1996, 2001) or the southern region (Geniez et al., 2004). However, there are still many knowledge gaps in distribution patterns, especially in poorly sampled and inaccessible regions, such as the AlgerianMoroccan frontier regions and the highest Rif and Atlas Mountains. Furthermore, since the seminal work of Bons \& Geniez (1996), there have been profound changes in the taxonomic status of multiple species (e.g. Wade, 2001; Carranza et al., 2004, 2006, 2008; Garcia-Porta et al., 2012; МetALLINou et al., 2012) and many works have collected additional distribution data for several species (e.g. IN DEN BosCH, 2005; Harris et al., 2008, 2010; Barata et al., 2011; de Pous et al., 2012; Beukema et al., 
2013). As such, the present work aims to: 1) revise the taxonomic list of amphibians and reptiles present in northern Morocco; 2) update the knowledge on the spatial distribution of amphibians and reptiles in northern Morocco at the $5 \times 5 \mathrm{~km}$ UTM grid scale; 3) identify areas of high amphibian and reptile species richness; and 4) identify preliminary relationships between species distribution and habitat variability. Ultimately, we expect to provide a framework basis for the definition of conservation strategies for these two taxonomic groups in northern Morocco.

\section{Materials ANd Methods}

\section{Study area}

The study area is located in northern Morocco and covers approximately 53013 $\mathrm{km}^{2}$. It is bordered by the Mediterranean Sea to the north, Algeria to the east, the Atlantic Ocean to the west, and minimum latitude of $\mathrm{N} 33.389$ degrees (datum WGS 1984) to the south (Fig. 1). The maximum altitude is $2548 \mathrm{~m}$ at Jbel Tazekka. The climate is mainly of Mediterranean type and it is characterised by high levels of precipitation and drainage, with an average annual rainfall and soil drainage above 1100 $\mathrm{mm}$. The high plains of eastern Morocco exhibit a hot and dry climate. Coastal areas experience moderate rainfall levels and temperature is milder in comparison with inland areas that exhibit a continental-type climate.

Limestone formations are relatively common in northern Tingitana Peninsula and east of the central Rif. To the east, the terrain becomes high and steep, with climbs reaching elevations of $1700 \mathrm{~m}$ (Jbel Tazaout), 1928 m (Jbel Kelti), 2050 m (Jbel
Tissouka) and $2170 \mathrm{~m}$ (Jbel Bouhalla, Jbel Lexhab and Jbel Lakraa). Sebou landscape is characterised by low altitude and mostly flat areas. Mountains of Beni Snassen have rock formations of limestone and can reach an altitude of $1530 \mathrm{~m}$. The north of Morocco is considered very rich and diverse in vegetation cover (BENABID, 1982; VALdÉs et al., 2002; VALDÉs, 2013). Major plant formations are generally of thermoMediterranean type (SAuvage, 1961), occurring in the Tingitana peninsula, the western and central Rif, Jbel Tazekka, Debdou and Beni Snassen mountains, but have been degraded in some areas and transformed into croplands and pastures in other places like the Gharb Basin and the eastern Rif.

\section{Taxonomic species list}

Since the publication of the lists developed by Bons (1972), Mellado \& DaKKI (1988), Bons \& Geniez (1996), Schleich et al. (1996) and Geniez et al. (2004), changes in species status have not ceased to modify the list and taxonomy of amphibians and reptiles of Morocco. In this study, we used the most updated and most complete taxonomic species data. For amphibians, we adopted the work of BEuKema et al. (2013), except for Bufo spinosus (GARcia-Porta et al., 2012; Recuero et al., 2012; Arntzen et al., 2013) and for the genus Discoglossus (Vences et al., 2014), for which D. scovazzi was separated from D. pictus. For reptiles, we took into account the following taxonomical considerations: we used Timon tangitanus -separated from Timon pater-, Scelarcis perspicillata and Podarcis vaucheri based on the revision of the phylogeny of Eurasian Lacerta by ArNold et al. (2007), discarded Acanthodactylus lineomacula- 


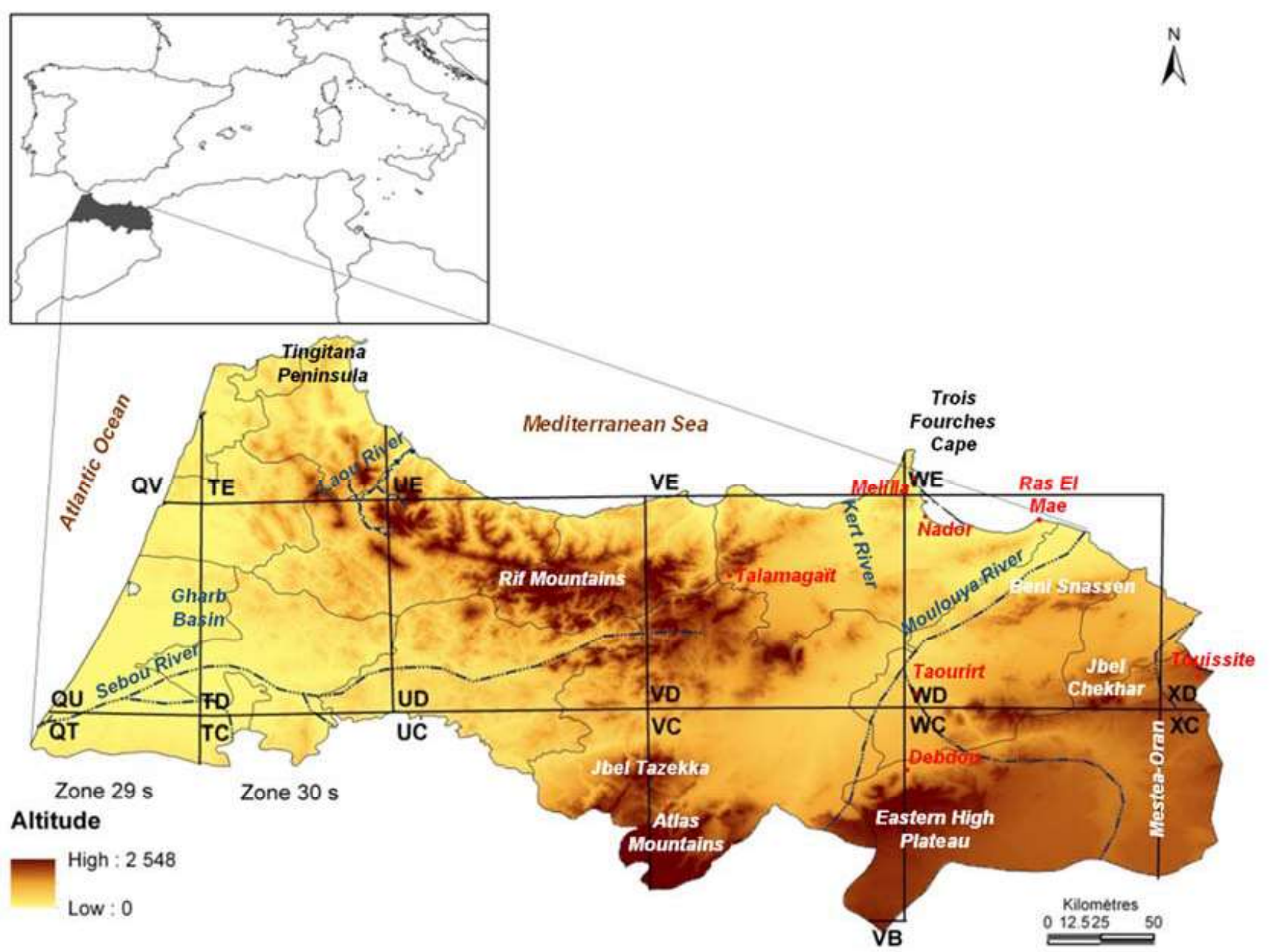

Figure 1: Location of the study area, altitudinal variation and identification of the main toponims cited in the text.

tus, which was lumped into Acanthodactylus erythrurus following Fonseca et al. (2009), used Agama impalearis after Brown et al. (2002), considered Trapelus boehmei based on WAGNER et al. (2011), used Uromastyx nigriventris following the genetic analyses of HARris et al. (2007) and Wilms et al. (2007), considered Stenodactylus mauritanicus after Metallinou et al. (2012) and Metallinou \& Crochet (2013), used Hyalosaurus koellikeri based on MACEY et al. (1999), followed for Macroprotodon snakes the works of WADE (2001) and CARRANZA et al. (2004), separating M. cucullatus from M. brevis and M. abubakeri, considered Malpolon insignitus after CARRANZA et al. (2006), and used Hemorrhois hippocrepis based on Nagr et al. (2004) and Daboia mauritanica following LENK et al. (2001).

\section{Species observations}

Published distributional data were gathered from the following works: Bons \& Geniez (1996), Fahd \& Pleguezuelos (1996, 2001), Brown et al. (2002), DonaireBarosso \& Bogaerts (2003), in den Bosch (2005), FAHd et al. (2005, 2007), PieH (2006), FAHd \& Mediani (2007), Guzmán et al. (2007), HARris et al. (2007, 2008, 2010), Carranza et al. (2008), Fonseca et al. (2008), Mediani et al. (2009), BARnESTEIn et al. (2010, 2012), El Hamoumi \& Нimmi 
(2010), Stoetzel et al. (2010), Barata et al. (2011), DE Pous et al. (2011a, 2012), Donaire et al. (2011a,b), Escoriza et al. (2011), Geniez et al. (2011), Garcia-Porta et al. (2012), Beukema et al. (2013), DamasMoreira et al. (2014) and Velo-Antón et al. (2014).

We also gathered data collected in the field since 1989 (amphibians), 1996 (saurians and amphisbaenians) or 2001 (snakes) until 2014. Sampling was not uniform across the study area; we focus sampling efforts in regions where previous knowledge about species distribution was rather limited. Sampling was conducted monthly during the whole year and the number of persons varied in each station from two to six. The geographic coordinates of observations collected before 1996 were gathered from maps with a 1:50 000 scale published by the French Institut Géographique National (IGN). Field observations collected after 1996 were georeferenced with a global positioning system (GPS) on the WGS 84 coordinate system.

Distribution atlas, species richness and relationships with land-cover

For each species present in our study area, distribution maps were produced representing all published observations in the earlier documents and our new fieldwork observations over a $5 \times 5 \mathrm{~km}$ UTM grid cell size (3088 cells in total). Distribution maps combined species for which the distribution limits are not yet clear (Discoglossus spp., Macroprotodon spp. and Malpolon spp.), or species of the same genus for which the number of citations was low (Saurodactylus spp.). For rare species $(\leq 13$

Table 1: Land-cover categories and their availability in the study area, including number of pixels (N) and percentage (\%) of occurrence (adapted from Bicheron et al., 2008).

\begin{tabular}{lccc}
\hline Land-cover category & Code & $\mathbf{N}$ & $\%$ \\
\hline Rain-fed croplands & CROP & 6690 & 7.12 \\
Rain-fed shrub or tree crops & SHRU & 11 & 0.01 \\
Mosaic of cropland (50-70\%) and vegetation (20-50\%) & CRVG & 20084 & 21.437 \\
Mosaic of vegetation (50-70\%) and cropland (20-50\%) & VGCR & 21179 & 22.53 \\
Closed ( $>40 \%$ ) broad-leaved deciduous forest $(>5 \mathrm{~m})$ & BRFO & 658 & 0.7 \\
Closed $(>40 \%$ ) needle-leaved evergreen forest & NEFO & 379 & 0.4 \\
Mosaic forest or shrub land / grassland & FOSH & 3689 & 3.93 \\
Closed to open $(>15 \%)$ shrub land $(<5$ m) & BNSH & 5875 & 6.325 \\
Closed to open $(>15 \%)$ broad-leaved deciduous shrub land $(<5$ m) & BRSH & 2470 & 2.63 \\
Sparse $(<15 \%)$ vegetation & VEGE & 7304 & 7.877 \\
Sparse $(<15 \%)$ grassland & GRAS & 7416 & 7.89 \\
Artificial surfaces and associated areas $(>50 \%)$ & URBA & 628 & 0.67 \\
Bare areas & BARE & 9396 & 10 \\
Consolidated bare areas & CONS & 7744 & 8.24 \\
Water bodies & WATE & 464 & 0.549 \\
\hline
\end{tabular}


observations) in the study area and also in Morocco, we provide the coordinates in 1 x $1 \mathrm{~km}$, whenever possible. These species include Chalcides ebneri, Chalcides mauritanicus, Chalcides parallelus, Psammodromus microdactylus, Psammodromus blanci, Ophisops occidentalis, T. pater and Eryx jaculus. We exclude from this list those species considered rare in our study but abundant in their distribution areas in Morocco (see Bons \& Geniez, 1996). Maps were produced using the Geographical Information System ArcGIS 10.0 (ESRI, Redlands, California, USA).

Three types of synthetic maps (i.e. richness of amphibians, richness of reptiles and total species richness) were generated by adding individual $5 \times 5 \mathrm{~km}$ presence observations of species using Spatial Analyst (ArcGIS).

The field observations georeferenced with a GPS were intersected with landcover categories (BICHERON et al., 2008; 250 $\mathrm{m}$ resolution; Table 1 ) to quantify preliminary patterns of habitat selection. Analyses were conducted using Spatial Analyst tool functions (ArcGIS).

\section{Results}

Overall, we identified and mapped distributions of 11 species of amphibians (1515 observations) and 53 of reptiles (3573 observations) in the study area (Table 2, Appendix 1).

Regarding species distribution patterns, four groups of amphibians and reptiles were identified: (1) species with widespread distribution, such as Amietophrynus mauritanicus, D. scovazzi, P. saharicus, A. erythrurus, A. impalearis, Mauremys leprosa, P. vaucheri, Psammodromus algirus,
Tarentola mauritanica, Natrix maura, H. hippocrepis and Malpolon monspessulanus; (2) species with limited and / or fragmented distribution, such as Salamandra algira, Alytes maurus, B. spinosus, Bufotes boulengeri, Pelobates varaldii, Pleurodeles waltl, Acanthodactylus boskianus, Acanthodactylus maculatus, Blanus tingitanus, Chalcides colosii, Chalcides minutus, Chalcides ocellatus, Chalcides pseudostriatus, Emys orbicularis, Mesalina olivieri, P. blanci, S. fasciatus, Saurodactylus mauritanicus, S. perspicillata, Stenodactylus mauritanicus, Trogonophis wiegmanni, Spalerosophis dolichospilus, Natrix natrix and D. mauritanica; (3) species that may be considered rare in northern Morocco, but apparently common throughout their distribution areas in Morocco, such as Chalcides mionecton, Chalcides polylepis, H. koellikeri, Mesalina guttulata, T. boehmei, Lytorhynchus diadema, M. cucullatus and S. dolichospilus; and (4) rare species with less than 13 observations, such as P. microdactylus, P. blanci, T. pater, O. occidentalis, C. ebneri, C. mauritanicus, C. parallelus and E. jaculus. Concerning the latter group, C. mauritanicus was recorded in two locations, the Moulouya River mouth and Ras El Mae (WD 5986 and WD 5587, respectively), C. parallelus was observed in six new locations in the Oriental Region (WD 5587, WD 2386, WD 1196, WD 1187, WD 2384 and WD 7256), and both P. blanci and O. occidentalis were recorded in two new locations (WC 9993 and WD 9502, and WC 3665 and WC 9993, respectively).

Several patterns of habitat selection were observed in the herpetofauna of northern Morocco (Table 2). All amphibians, Testudines and Scincidae were frequently linked to mosaics with combina- 


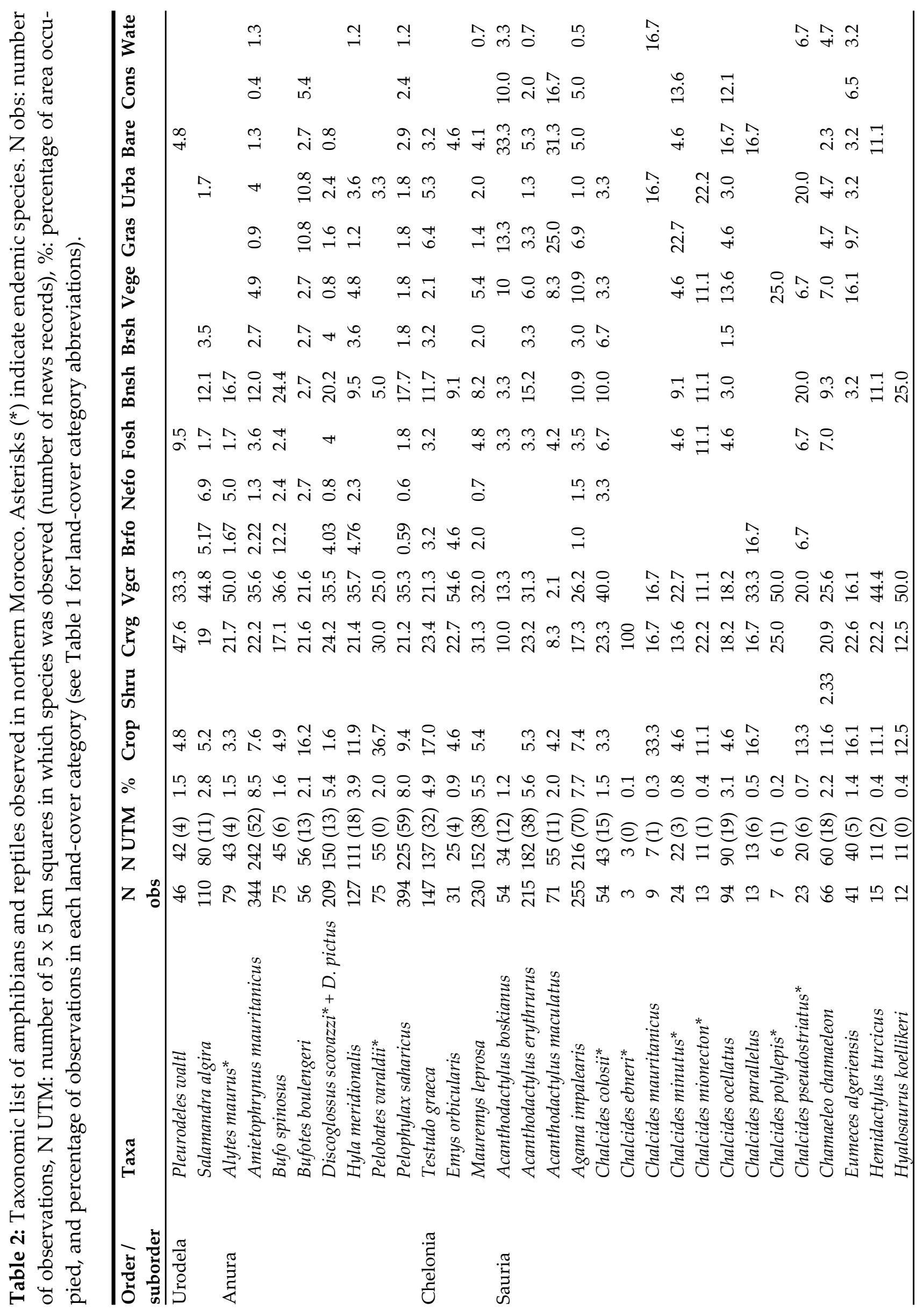




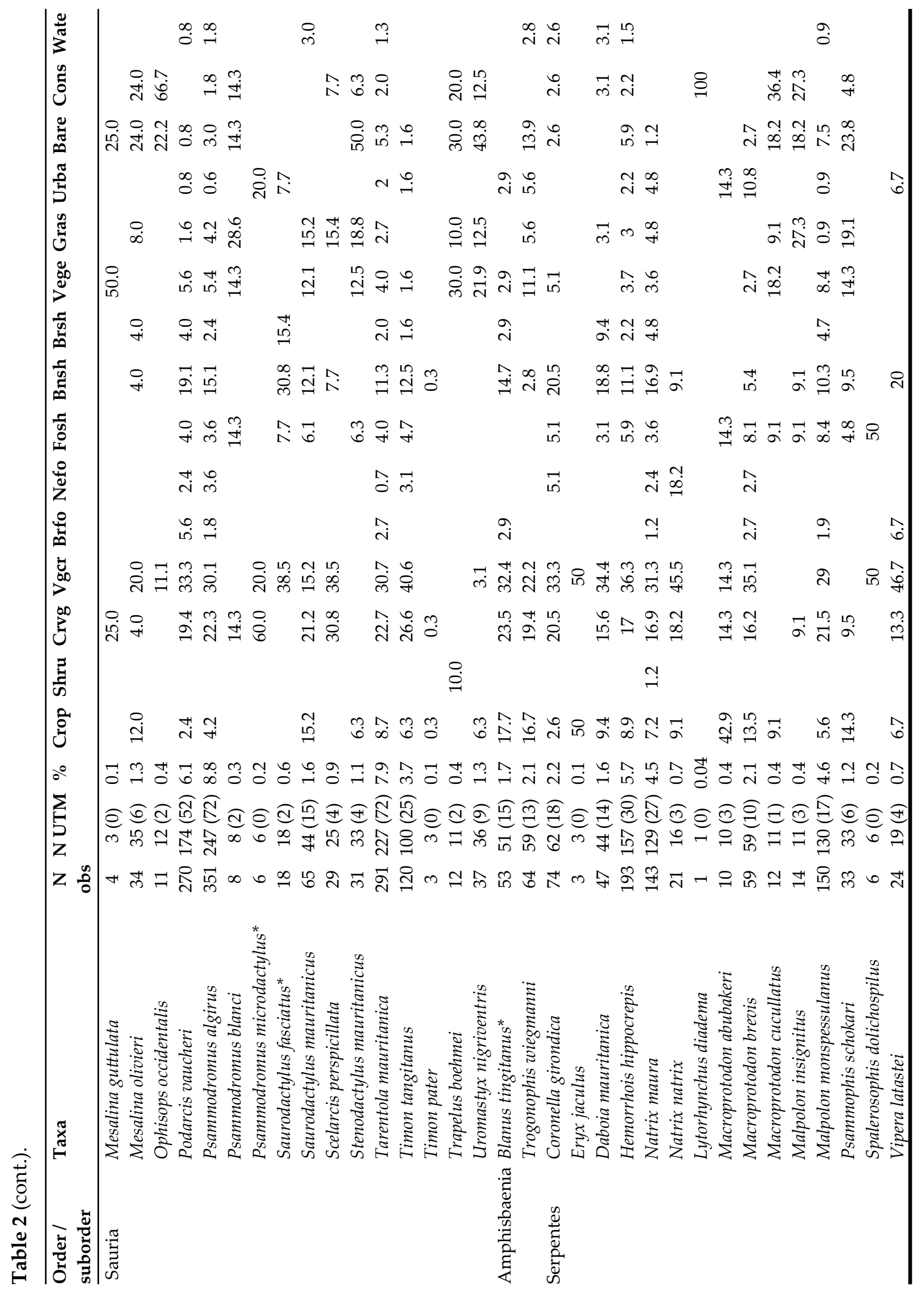


Figure 2: Representation in UTM $5 \times 5 \mathrm{~km}$ grid of (A) amphibian species richness, (B) reptile species richness, and (C) total species richness in northern Morocco.
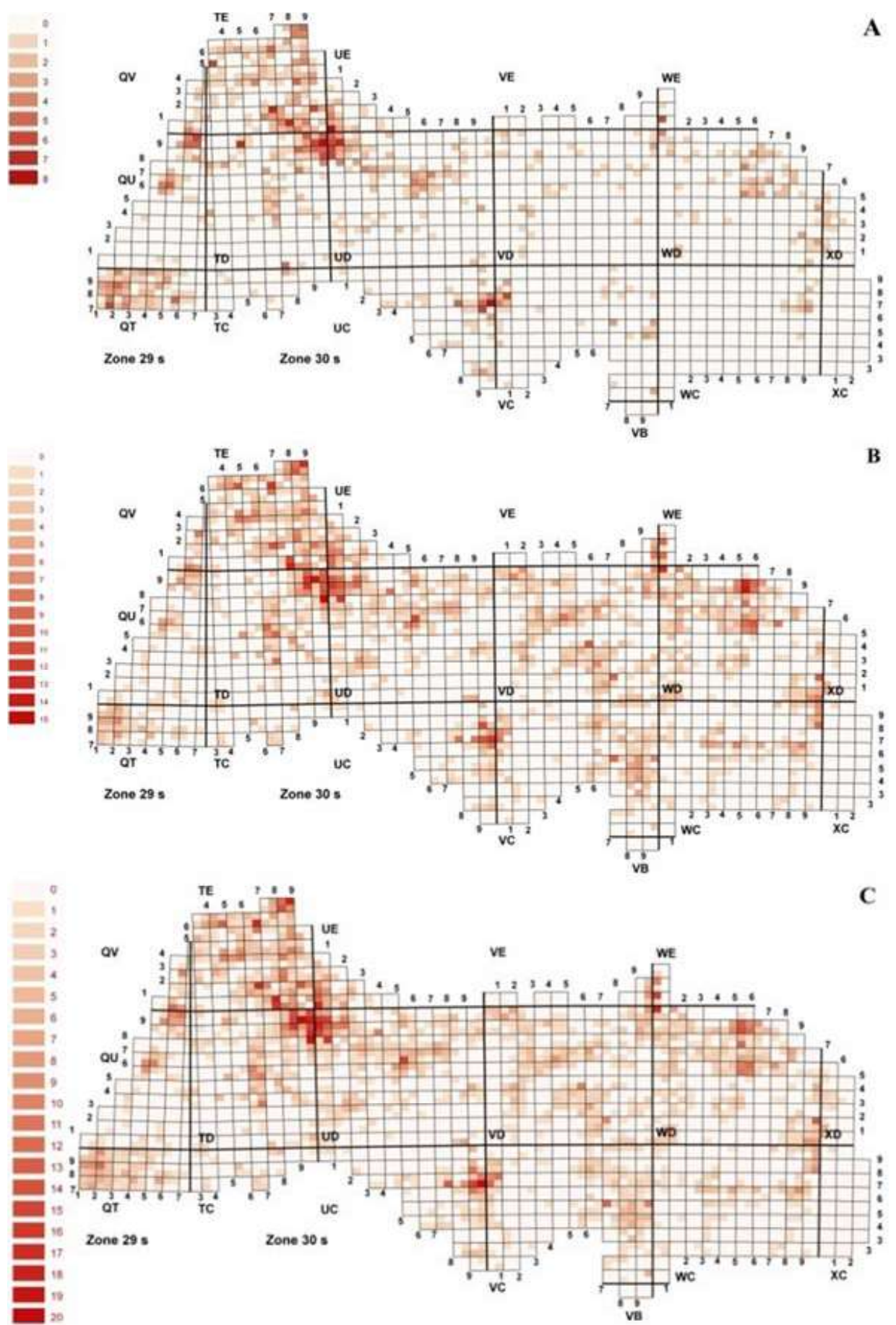

tions of vegetation and croplands, where some species from the other taxonomic groups were also frequently found, including Chamaeleo chamaeleon, H. koellikeri, Eumeces algeriensis, P. microdactylus, S. fasciatus, S. perspicillata, T. tangitanus, T. wiegmanni, E. jaculus, Coronella girondica, D. mauritanica, N. natrix, S. dolichospilus, M. brevis and $M$. abubakeri. Other species such as $B$. boulengeri, P. saharicus, A. erythrurus, $A$. impalearis, P. vaucheri, P. algirus, T. mauritanica, N. maura and M. monspessulanus exhibited relatively general patterns of habitat selection. Finally, there are few species associated with desert habitats, including A. boskianus, A. maculatus, Saurodactylus 
mauritanicus, O. occidentalis, P. blanci, $U$. nigriventris, L. diadema, M. cucullatus, M. insignitus and Psammophis schokari.

Areas of relatively high amphibian species richness were highly fragmented and located in the western Rif, Tingitana Peninsula, Mamoura Forest (Gharb Basin), Jbel Tazekka, along the Atlantic coast, and in a narrow stripe in the north-east (Fig. 2a). A large number of reptile species were located in the Tingitana Peninsula, western Rif, Jbel Tazekka, Trois Fourches Cape, the mouth of Moulouya River and Jbel Chekhar. Other relatively rich areas for reptiles are located along the high plains of the oriental and central Rif, pre-Rif and Mamoura Forest (Fig. 2b). The distribution of total species richness follows the same patterns exhibited by the distribution of reptile's richness (Fig. 2c).

\section{Discussion}

Northern Morocco hosts 11 species of amphibians and 53 species of reptiles. These 64 species represent $56 \%$ of the herpetofauna of Morocco, which is a relatively high proportion in comparison to the relative surface of the study area (about $7.5 \%$ of Morocco). About 31.6\% and 34.7\% of the observations of amphibians and reptiles, respectively, are new localities, while the remaining fractions predominantly come from published references for amphibians (Bons \& Geniez, 1996; Beukema et al., 2013) and reptiles (Bons \& GeNiez, 1996; Fahd \& Pleguezuelos, 1996, 2001). All amphibians and reptiles of northern Morocco were included in this study with the exception of sea turtles and two terrestrial reptiles (Psammodromus hispanicus and Cerastes cerastes). The former was considered by several authors as introduced in Morocco (Melilla and Sidi Ifni; de Zulueta, 1909; Joleaud, 1934), while the presence of $C$. cerastes in the plain of Tafrata near Debdou (Laurent, 1935) has been considered as doubtful (Bons \& Geniez, 1996).

Given that sampling effort was not uniform along space and time, interpretations of distribution maps of individual species and species richness should be made with care. In particular, the frontier areas with Algeria, some mountains of Beni Snassen, between Taourirt and Touissite and some oriental Rif mountains were not visited. Future fieldwork sampling efforts should concentrate on those areas in order to update distribution maps.

Species distribution maps were updated according to our field observations and literature. Some old observations were reevaluated and in some cases they were considered as erroneous and excluded from our study. These observations included A. maurus in the Tingitana Peninsula (see Bons \& Geniez, 1996) and three records of Vipera lataste $i$ at Trois Fourches Peninsula and Oued Kert (Yus Ramos \& Cabo Hernández, 1986). On the contrary, the single observation of E. orbicularis in the eastern Rif (FAhD \& Pleguezuelos, 1996) was considered in this work because there are recent photographic evidences of the species presence in this region. We also gave veracity to the observation of $P$. waltl at Talamagaï (MАтеo, 1991), despite our intense sampling in eastern Rif and in this locality failed to find the species. However, there are some local guides confirming its presence. Further research should be conducted throughout the eastern region to determine the specific status of $P$. waltl 
in this area.

In comparison with the previous atlases of distribution of amphibians and reptiles in Morocco (Bons \& Geniez, 1996; Fahd \& Pleguezuelos, 1996, 2001; Beukema et al., 2013), new observations were recorded outside the known distribution area for one amphibian and three reptile species. The amphibian, B. boulengeri, was recorded in several localities of the western Rif (UE 0404, TD 9891, UD 1188 and UD 0185), as well as in the watershed of Oued Laou (western Rif) by FaHd \& Mediani (2007). This species had been considered absent from this region by previous works (Donaire et al., 2011b; Beukema et al., 2013), probably because of lack of prospection in the localities mentioned above. Regarding reptiles, C. pseudostriatus was observed (May 2002) in a wetland of the Moulouya River (WD 5453), an area probably inhabited also by C. minutus, as the two species are known to occur in sympatry in the Middle Atlas Mountains (Geniez \& Sото, 1994). This species was recorded in southern Debdou (VC9758, DamasMoreira et al., 2014), also outside its previously known distribution range. These two observations merit more attention in future genetic analyses, because the identification of these two specimens was based on morphological analyses only. Finally, $S$. perspicillata was recorded at the Beni Snassen Mountain in 2010 and 2014 (WD 7256). Taken in combination, these new observations extended significantly the known distribution areas of these three species in northern Morocco. Additionally, the records that we have compiled in the present work also contributed to extend the known ranges of $P$. varaldii and $N$. natrix, which can be attributed to increased sampling efforts in recent years by both professional and amateur herpetologists (e.g. Pieh, 2006; Guzmán et al., 2007; Harris et al., 2008, 2010; BARNESTEIN et al., 2010, 2012; BARATA et al., 2011; DonAIre et al., 2011a).

During our field expeditions in northern Morocco, contact zones between parapatric Discoglossus species were sampled. According to phylogenetic and morphological reviews of the genus, D. scovazzi clearly differs from its congener $D$. pictus by the absence of tympanum (FromHAGE et al., 2004; Martínez-Solano et al., 2004; ZANGARI et al., 2006; PABIJAN et al., 2012). The former species has a wide distribution, from the Atlantic Coast to the west of Moulouya Basin, while the latter species occurs on the eastern side of Moulouya River (Beukema et al., 2013; Vences et al., 2014). In eastern Morocco, all sampled populations examined east of the Moulouya River were clearly assignable to $D$. pictus. This species was also found along the Mediterranean Coast west of Moulouya River, in the cities of Nador and Melilla, suggesting that the potential barrier to the distribution of these frogs corresponds to the wide and arid river valley and not to the river itself (Vences et al., 2014). During our field expeditions, sampling of localities north of the Moulouya Valley was unable to detect sympatry between D. scovazzi and D. pictus, which further supports the genetic revisions of Vences et al. (2014).

Three species of Macroprotodon snakes are known to occur in Morocco (M. abubakeri, M. cucullatus and M. brevis) according to the latest revision on the genus (WADE, 2001; Carranza et al., 2004). During our field expeditions in the Trois Fourches 
Peninsula, no specimens of M. abubakeri were found west of Moulouya Valley. Nevertheless, Wade (2001) attributed to $M$. abubakeri the specimens found in two localities west of the Moulouya Valley (Ras El Mae), which shows that the Moulouya River does not act as a geographic barrier for the species. Therefore, the exact distribution limits between M. brevis and M. abubakeri remain unknown and the occurrence of contact zones is highly probable (WADE, 2001; Carranza et al., 2004). The same problem was found with M. cucullatus and $M$. brevis because their distribution limits were apparently not related with geographical barriers. Because of these difficulties in determining the limits of their distribution areas, the three species were combined into a single map (Appendix 1). Both ecological and genetic studies are needed in order to better understand the habitat selection patterns of these species and how genetic diversity is spatially structured.

According to our study, the northwestern limit between the snakes of the genus Malpolon (M. insignitus and M. monspessulanus) is not very clear, but apparently the Moulouya Valley might be acting as a barrier between these two species to the southeast. Malpolon insignitus, once considered a subspecies of $M$. monspessulanus, was elevated to the rank of species by the phylogenetic study of CARRANzA et al. (2006), and most citations of this species are found in the valley of Moulouya, at the eastern high plateau (Bons \& GENiEz, 1996). An intermediate form between $M$. monspessulanus and M. insignitus, based on morphological characteristics, was discovered at Saïdia (Geniez et al., 2006) suggesting the possibility of hybridization be- tween these two species. Further detailed studies on genetic and phenotypic diversity in contact zones are needed to understand population dynamics.

The distribution maps of many species show a trend for more or less contiguous observations, suggesting that their areas of distribution are fairly well documented. These species include $A$. mauritanicus, $P$. saharicus, D. scovazzi, A. erythrurus, A. impalearis, C. ocellatus, $H$. hippocrepis, M.monspessulanus, M. leprosa, N. maura, P. algirus and T.mauritanica, and particularly those species that have been subject of previous detailed studies, such as A.maurus, S. algira, Discoglossus spp., P. varaldii and Macroprotodon spp.. On the contrary, some species reported previously in northern Morocco, such as $C$. cerastes and P. hispanicus, require more detailed studies to confirm their presence in the region. The lizards Acanthodactylus savignyi, Acanthodactylus dumerili and $P$. vaucheri have been documented in the western regions of Algeria (Salvador, 1982; Arnold, 1983, Bons \& Geniez, 1996), suggesting their likely presence in eastern Morocco as well. Recently, A. maurus was recorded in the neighbouring Tlemcen province in Algeria (LoukKas, 2006), and its presence suggested in northeastern Morocco, particularly in the wettest environments of the highlands of Debdou and Meseta-Oran, as shown by ecological modelling (DE Pous et al., 2013). To clarify the status of these species in north-eastern Morocco, further sampling is required. For other species, such as C.ebneri, E. jaculus, T. pater, S. dolichospilus, $P$. microdactylus, P. varaldii, M. guttulata and $H$. koellikeri, no new records were made, suggesting also that further sampling is need- 
ed in particular areas of northern Morocco.

The majority of new data collected in our study comes from the Tingitana Peninsula and western Rif, while the central and eastern Rif, the Gharb, the Middle Atlas, and eastern Morocco (highlands of Debdou, Beni Snassen Mountain, and regions in the border with Algeria) remain poorly studied. The interpretations of distribution maps should take into account such geographical sampling bias. Still, important observations were made in those regions. For instance, C. pseudostriatus and S. perspicillata were recorded for the first time in the eastern region of northern Morocco, and $P$. waltl was observed in the eastern Rif, far from the previously known range of the species.

Concerning patterns of habitat selection, the main results are supported by previous works on the subject (e.g. Bons \& Geniez, 1996; Real et al., 1997; Fahd \& PleGUEZUElos, 2001). All amphibians apparently occur outside the semi-desert areas, in habitats with important primary production (mosaics of cropland and natural vegetation). These habitats are found mainly in north-western Morocco, in areas with high levels of precipitation. Eastern Morocco is much drier and the majority of habitats found in the south-east correspond to bare areas, which results in reduced species richness. One of the most obvious and direct effects of reduced rainfall on the herpetofauna is the scarcity of breeding sites for amphibians. According to our data, croplands would constitute a breeding habitat for most amphibians in northern Morocco, which is consistent with other observations (DE Pous et al., 2011b; Beukema et al., 2013). For reptiles, there are apparently three groups of spe- cies according to their habitat selection patterns: 1) species occupying the arid regions of the eastern plains dominated by bare soil or with some vegetation cover, 2) generalist species usually exhibiting wide distributions across northern Morocco, and 3) species occupying Mediterranean environments that are usually abundant in north-western regions.

The distribution patterns of observed richness of amphibians, reptiles and herpetofauna in general were almost similar. The highest species richness was observed along a large area of the central and western Rif. These regions correspond to the most humid bioclimatic zone of Morocco (EMberger, 1962; BenAbid, 1982, 2000) and support also rich and diversified forest communities, including Abies marocana, Cedrus atlantica, Quercus suber, Quercus ilex, Quercus canariensis and Quercus fructicosa (VALDÉs et al., 2002). For the herpetofauna, these regions tend to harbour species of different biogeographical origins, which originates a high species richness. These species include those of Palaearctic affinity, resulting from faunal exchange between Africa and Europe during geological times (STEININGer et al., 1985), and those of sub-Saharan origin which tend to follow the arid corridor of the Moulouya River Valley (Fahd \& Pleguezuelos, 1996; Real $e t$ al., 1997).

The distribution maps presented here constitute framework tools for future establishment of new potential protected areas or enlargement of the current ones.

\section{Acknowledgement}

We would like to thank Haut Commissariat aux Eaux et Forêts et à la Lutte Con- 
tre la Désertification (HCEFLCD) for all permits and assistance in the fieldworks during all years. Part of this study was funded by Convention cooperative CNRST / FCT (GRICES. Portugal), 88908/09. José Carlos Brito is supported by a FCT contract (IF/00459/2013). Study supported by project "Biodiversity patterns in amphibians and reptiles of North Africa" (Proc. 4.1.5 CNRST/Morocco). We would like to thank the editors Ana Perera and Manuel Ortiz-Santaliestra as well as two anonymous reviewers for their helpful comments that improved the manuscript.

\section{REFERENCES}

Anderson, R.P.; Gómez-Laverde, M. \& Peterson, A.T. (2002). Geographical distributions of spiny pocket mice in South America: insights from predictive models. Global Ecology and Biogeography 11: 131-141.

Arnold, E.N. (1983). Osteology, genitalia and the relationships of Acanthodactylus (Reptilia: Lacertidae). Bulletin of the British Museum of Natural History (Zoology) 44: 291339.

Arnold, E.N.; Arribas, O. \& Carranza, S. (2007). Systematics of the Palaearctic and Oriental lizard tribe Lacertini (Squamata: Lacertidae: Lacertinae), with descriptions of eight new genera. Zootaxa 1430: 1-86.

Arntzen, J.W.; McAtear, J.; Recuero, E.; Ziermann, J.M.; Ohler, A.; van Alphen, J. \& Martínez-Solano, I. (2013). Morphological and genetic differentiation of Bufo toads: two cryptic species in Western Europe (Anura, Bufonidae). Contributions to Zoology 82: 147-169.

Ayllón, E.; Bustamante, P.; Cabrera, F.; Flox, L.; Galindo, A.J.; Gosálvez, R.U.; HernánDez, J.M.; Morales, M.; Torralvo, C. \& ZAMORA, F. (2002-2003). Atlas provisional de distribución de los anfibios y reptiles de la provincia de Ciudad Real (Castilla-La Mancha, España). Zoologica Baetica 13/14: 155202.

Barata, M.; Perera, A.; Harris, D.J.; Van Der Meijden, A.; Carranza, S.; Ceacero, F.; García-Muñoz, E.; Gonçalves, D.; Henriques, S.; Jorge, F.; Marshall, J.C.; Pedrajas, L. \& Sousa, P. (2011). New observations of amphibians and reptiles in Morocco, with a special emphasis on the eastern region. Herpetological Bulletin 116: 4-14.

Barnestein, J.A.M.; González de la Vega, J.P.; JimÉnEz-CAZALla, F. \& Gabari-BoA, V. (2010). Contribución al atlas de la herpetofauna de Marruecos. Boletín de la Asociación Herpetológica Española 21: 76-82.

Barnestein, J.A.M.; Donaire-Barroso, D.; González de la Vega, J.P.; Valdeón, A. \& EL Mouden, E.H. (2012). Contribución al conocimiento de la herpetofauna de Marruecos: Nuevos datos corológicos (octubre 2003). Butlletí de la Societat Catalana d'Herpetologia 20: 57-71.

Belqat, B. \& Adler, P.H. (2001). Distribution du genre Prosimulium Roubaud (Diptera, Simuliidae) dans le Rif (Nord du Maroc). Zoologica Baetica 12 : 119-134.

Benabid, A. (1982). Etudes Phytoécologique, Biogéographique et Dynamique des Associations et Séries Sylvatiques du Rif Occidental (Maroc): Problèmes Posés par la Reforestation et l'Aménagement des Peuplements Forestiers Actuels. Ph.D. Dissertation, Université Paul Cézanne, Aix-en-Provence - Marseille, France.

Benabid, A. (2000). Flore et Écosystèmes du Maroc. Evaluation et Préservation de la Biodiversité. Ibis Press, Paris, France.

Bennas, N.; Sáinz-Cantero, C.E. \& Ouarour, A. (2001). Nouvelles données sur les coléoptères aquatiques du Maroc: les Hydraenidae Mulsant, 1844 (Coleoptera) du Rif. Zoologica Baetica 12: 135-168.

Beukema, W.; de Pous, P.; Donaire-Barroso, D.; Bogaerts, S.; Garcia-Porta, J.; Escoriza, D.; Arribas, O.J.; El Mouden, E.H. \& Carranza, S. (2013). Review of the system- 
atics, distribution, biogeography and natural history of Moroccan amphibians. Zootaxa 3661: 1-60.

Bicheron, P.; Defourny, P.; Brockmann, C.; Schouten, L.; Vancutsem, C.; Huc, M.; Bontemps, S.; Leroy, M.; Achard, F.; Herold, M.; Ranera, F \& Arino, O. (2008). GLOBCOVER. Products Description and Validation Report. Medias-France, Toulouse, France. Available at http://due.esrin.esa.int/ page_globcover.php. Retrieved on 09/21/2009.

Bons, J. (1972). Herpétologie marocaine. 1. Liste commentée des amphibiens et reptiles du Maroc. Bulletin de la Société des Sciences Naturelles et Physiques du Maroc 52 : 107-126.

Bons, J. \& Geniez, P. (1996). Amphibiens et Reptiles du Maroc (Sahara Occidental Compris). Atlas Biogéographique. Asociación Herpetológica Española, Barcelona, Spain.

Brown, R.P.; Suárez, N.M. \& Pestano, J. (2002). The Atlas mountains as a biogeographical divide in North-West Africa: evidence from mtDNA evolution in the Agamid lizard Agama impalearis. Molecular Phylogenetics and Evolution 24: 324-332.

Carranza, S.; Arnold, E.N.; Wade, E. \& FAhD, S. (2004). Phylogeography of the false smooth snakes, Macroprotodon (Serpentes, Colubridae): mitochondrial DNA sequences show European populations arrived recently from Northwest Africa. Molecular Phylogenetics and Evolution 33: 523-532.

Carranza, S.; Arnold, E.N. \& Pleguezuelos, J.M. (2006). Phylogeny, biogeography, and evolution of two Mediterranean snakes, Malpolon monspessulanus and Hemorrhois hippocrepis (Squamata, Colubridae), using mtDNA sequences. Molecular Phylogenetics and Evolution 40: 532-546.

Carranza, S.; Arnold, E.N.; Geniez, P.; Roca, J. \& MAteO, J.A. (2008). Radiation, multiple dispersal and parallelism in the skinks, Chalcides and Sphenops (Squamata: Scincidae), with comments on Scincus and Scincopus and the age of the Sahara Desert. Molecular
Phylogenetics and Evolution 46: 1071-1094. Damas-Moreira, I.; Tomé, B.; Harris, D.J.; MaIA, J.P. \& SALVI, D. (2014). Moroccan herpetofauna: distribution updates. Herpetozoa 27: 96-102.

de Pous, P.; Mora, E.; Metallinou, M.; Escoriza, D.; Comas, M.; Donaire, D.; PleguezueLos, J.M. \& Carranza, S. (2011a). Elusive but widespread? The potential distribution and genetic variation of Hyalosaurus koellikeri (Günther, 1873) in the Maghreb. AmphibiaReptilia 32: 385-397.

de Pous, P.; Beukema, W.; Weterings, M.; DüMMER, I. \& Geniez, P. (2011b). Area prioritization and performance evaluation of the conservation area network for the Moroccan herpetofauna: a preliminary assessment. Biodiversity and Conservation 20: 89-118.

de Pous, P.; Beukema, W.; Dingemans, D.; Donaire, D.; Geniez, P. \& El Mouden, E.H. (2012). Distribution review, habitat suitability and conservation of the endangered and endemic Moroccan spadefoot toad (Pelobates varaldii). Basic and Applied Herpetology 26: 57-71.

de Pous, P.; Metallinou, M.; DonaireBarroso, D.; Carranza, S. \& SanuY, D. (2013). Integrating mtDNA analyses and ecological niche modelling to infer the evolutionary history of Alytes maurus (Amphibia; Alytidae) from Morocco. Herpetological Journal 23: 153-160.

de Zulueta, A. (1909). Nota sobre reptiles de Melilla (Marruecos). Boletín de la Real Sociedad Española de Historia Natural 10: 351354.

Donaire, D.; del Canto-Gónzalez, R.; Bogaerts, S.; Pasmans, F. \& El Mouden, E.H. (2011a). Nuevas localidades para Emys orbicularis occidentalis Fritz, 1993 (Testudines: Emydidae) en el Rif (Noroeste de Marruecos). Butlletí de la Societat Catalana d'Herpetologia 19: 125-129.

Donaire, D.; Beukema, W.; de Pous, P. \& Del Canto Gonzalez, R. (2011b). A distributional review of Bufo boulengeri Lataste, 
1879 in northern Morocco with emphasis on occurrence in the Rif Mountains. Herpetology Notes 3: 71-74.

Donaire-Barroso, D. \& Bogaerts, S. (2003): Datos sobre taxonomía, ecología y biología de Alytes maurus (Pasteur \& Bons, 1962) (Anura; Discoglossidae). Butlletí de la Societat Catalana d'Herpetologia, 16, 25-41.

El Haissoufi, M.; Bennas, N.; El Mohdi, O. \& Millán, A. (2010). Analyse préliminaire de la vulnérabilité des odonates (Odonata) du Rif occidental (nord du Maroc). Boletín de la Sociedad Entomológica Aragonesa 46: 345354.

El Hamoumi, R. \& Himmi, O. (2010). Distribution et état des lieux des peuplements d'Amphibiens dans le complexe de zones humides du bas Loukkos (Larache, Maroc). Bulletin de l'Institut Scientifique, Rabat, Section Sciences de la Vie 32: 95-100.

Emberger, L. (1962). Carte Bioclimatique de la Région Méditerranéenne $1: 5,000,000$. Institut Géographique National - UNESCO - FAO, Paris, France.

Escoriza, D.; Fuentes, M.A. \& Comas, M.M. (2011). Natrix natrix (Squamata: Colubridae) presence in Sidi Boughaba Ramsar Reserve (North-western Morocco). Butlletí de la Societat Catalana d'Herpetologia 19: 119-121.

FAHd, S. \& Mediani, M. (2007). Herpétofaune du bassin versant de Oued Laou. Report Wadi $6^{\circ}$ FP, INCO-CT2005-015226, Tétouan, Morocco. Available at http://www.wadi.unifi.it/ results_fahd_mediani_herpetofauna.pdf. Retrieved on 06/13/2008.

Fahd, S. \& Pleguezuelos, J.M. (1996). Los reptiles del Rif (norte de Marruecos), I: Quelonios, Saurios. Revista Española de Herpetología 10: 55-89.

Fahd, S. \& Pleguezuelos, J.M. (2001). Los reptiles del Rif (Norte de Marruecos), II: anfisbenios y ofidios. Comentarios sobre la biogeografía del grupo. Revista Española de Herpetología 15: 13-36.

Fahd, S.; Benítez, M.; Brito, J.C.; Caro, J.; Chirosa, M.; Feriche, M.; FernándeZ-
Cardenete, J.R.; Martínez-Freira, F.; Márquez-Ferrando, R.; Nesbitt, D.; PleguezueLos, J.M.; Reques, R.; Rodríguez, M.P.; SANTos, X. \& Sicilia, M. (2005). Distribución de Vipera latasti en el Rif y otras citas herpetológicas para el norte de Marruecos. Boletín de la Asociación Herpetológica Española 16: 19-25.

Fahd, S.; Barata, M.; Benítez, M.; Brito, J.C.; Caro, J.; Carvalho, S.; Chirosa, M.; Feriche, M.; Herrera, T.; Márquez-Ferrando, R.; Nesbitt, D.; Pleguezuelos, J.M.; Reques, R.; Rodríguez, M.P.; Santos, X.; Sicilia, M. \& Vasconcelos, R. (2007). Presencia de la víbora hocicuda Vipera latastei en el Atlas Medio (Marruecos) y otras citas herpetológicas para la región. Boletín de la Asociación Herpetológica Española 18: 26-34.

Fonseca, M.M.; Brito, J.C.; Rebelo, H.; KaLboussi, M.; Larbes, S.; Carretero, M.A. \& HARRIS, D.J. (2008). Genetic variation among spiny-footed lizards in the Acanthodactylus pardalis group from North Africa. African Zoology 43: 8-15.

Fonseca, M.M.; Brito, J.C.; Paulo, O.S.; CarreTERo, M.A. \& HARris, D.J. (2009). Systematic and phylogeographical assessment of the Acanthodactylus erythrurus group (Reptilia: Lacertidae) based on phylogenetic analyses of mitochondrial and nuclear DNA. Molecular Phylogenetics and Evolution 51: 131-142.

Fritz, U.; Fritzsch, G.; Lehr, E.; Ducotterd, J.M. \& Müller, A. (2005). The Atlas Mountains, not the Strait of Gibraltar, as a biogeographic barrier for Mauremys leprosa (Reptilia: Testudines). Salamandra 41: 97106.

Fromhage, L.; Vences, M. \& Veith, M. (2004). Testing alternative vicariance scenarios in Western Mediterranean discoglossid frogs. Molecular Phylogenetics and Evolution 31: 308322.

Garcia-Porta, J.; Litvinchuk, S.N.; Crochet, P.A.; Romano, A.; Geniez, P.H.; Lo-Valvo, M.; Lymberakis, P. \& Carranza, S. (2012). Molecular phylogenetics and historical biogeography of the west-Palearctic common 
toads (Bufo bufo species complex). Molecular Phylogenetics and Evolution 63: 113-130.

Geniez, P. \& Soto, P. (1994). Nouvelles observations sur l'herpétofaune marocaine, 5. Bulletin de la Société Herpétologique de France 6970: 33-39.

Geniez, P.; Mateo, J.A.; Geniez, M. \& Pether, J. (2004). The amphibians and Reptiles of the Western Sahara (Former Spanish Sahara) and Adjacent Regions. Edition Chimaira, Frankfurt am Main, Germany.

Geniez, P.; Cluchier, A. \& de HaAn, C.C. (2006). A multivariate analysis of the morphology of the colubrid snake Malpolon monspessulanus in Morocco and Western Sahara: biogeographic and systematic implications. Salamand ra 42: 65-82.

Geniez, P.; Padial, J.M. \& Crochet, P.-A. (2011). Systematics of north African Agama (Reptilia: Agamidae): a new species from the central Saharan mountains. Zootaxa 3098, 26-46.

Guzmán, J.L.; Ceacero, F. \& García-Muñoz, E. (2007). Nuevas citas de anfibios y reptiles en Marruecos. Munibe 25: S82-S87.

Harris, D.J.; Carretero, M.A.; Perera, A.; Pérez-Mellado, V. \& Ferrand, N. (2003). Complex patterns of genetic diversity within Lacerta (Teira) perspicillata: Preliminary evidence from 12S rRNA sequence data. Amphibia-Reptilia 24: 386-390.

Harris, D.J.; Vasconcelos, R. \& BRIto, J.C. (2007). Genetic variation within African spiny-tailed lizards (Agamidae: Uromastyx) estimated using mitochondrial DNA sequences. Amphibia-Reptilia 28: 1-6.

Harris, D.J.; Carretero, M.A.; Brito, J.C.; Kaliontzopoulou, A.; Pinho, C.; Perera, A.; Vasconcelos, R.; Barata, M.; Barbosa, D.; Carvalho, S.; Fonseca, M.M.; PérezLanuza, G. \& Rato, C. (2008). Data on the distribution of the terrestrial herpetofauna of Morocco: records from 2001-2006. Herpetological Bulletin 103: 19-28.

Harris, D.J.; Perera, A.; Barata, M.; Tarroso, P. \& SAlvi, D. (2010). New distribution notes for terrestrial herpetofauna from Morocco. North-Western Journal of Zoology 6: 309-315.

Hirzel, A.H.; Hausser, J.; Chessel, D. \& Perrin, N. (2002). Ecological-niche factor analysis: how to compute habitat-suitability maps without absence data? Ecology 83: 20272036.

IN DEN Bosch, H.A.J. (2005). Psammodromus microdactylus (Boettger, 1881), a rare lizard species? Podarcis 6: 1-35.

Joleaud, L. (1934). La Faune Terrestre et des Eaux Douces du Maroc. Vertébrés. Imprimeries Réunies, Moulins, France.

Laurent, P. (1935). Contribution à la connaissance de la faune des vertèbres du Maroc (Batraciens, Reptiles, Mammifères). Bulletin de la Société d'Histoire Naturelle d'Afrique du Nord 26: 344-359.

Lenk, P.; Kalyabina, S.; Wink, M. \& Joger, U. (2001). Evolutionary relationships among the true vipers (Reptilia, Viperidae) inferred from mitochondrial DNA sequences. Molecular Phylogenetics and Evolution 19: 94-104.

Loukkas, A. (2006). Atlas des Parcs Nationaux Algériens. République Algérienne Démocratique et Populaire, Ministère de l'Agriculture et du Développement Rural, Direction Générale des Forêt, Parc National de Théniet El Had, Alger, Algeria. Available at http:// www.fichier-pdf.fr/2010/12/19/atlas-desparcs-nationaux/. Retrieved on 07/19/2009.

Macey, J.R.; Schulte II, J.A.; Larson, A.; Tuniyev, B.S.; Orlov, N. \& Papenfuss, T.J. (1999). Molecular phylogenetics, tRNA evolution, and historical biogeography in anguid lizards and related taxonomic families. Molecular Phylogenetics and Evolution 12: 250-272.

Martínez-Freiría, F.; Argaz, H.; Fahd, S. \& BRITO, J.C. (2013). Climate change is predicted to negatively influence Moroccan endemic reptile richness. Implications for conservation in protected areas. Naturwissenschaften 100: 877-889.

Martínez-Solano, I.; Gonçalves, H.A.; Arntzen, J.W. \& García-París, M. (2004). Phylogenetic relationships and biogeogra- 
phy of midwife toads (Discoglossidae: Alytes). Journal of Biogeography 31: 603-618.

Mateo, J.A. (1991). Los anfibios y reptiles de Ceuta, Melilla, Chafarinas, Peñón de Vélez de la Gomera, Peñón de Alhucemas e islotes. Revista Española de Herpetología 5: 3741.

MÉDAIL, F., \& QuÉzel, P. (1999). Biodiversity hotspots in the Mediterranean Basin: setting global conservation priorities. Conservation Biology 13: 1510-1513.

Mediani, M.; Amezian, M.; Ibn Tattou, M.; Benhoussa, A.; Rguibi Idrissi, H.; El AgbaNI, M.A. \& QninbA, A. (2009). Nouvelles citations de deux espèces reliques paléarctiques, Emys orbicularis Linnaeus, 1758 et Vipera latastei Boscá, 1878 dans la Péninsule Tingitane (Rif occidental, Maroc). Bulletin de l'Institut Scientifique, Rabat, Section Sciences de la Vie 31: 99-102.

Mellado, J. \& DAKKI, M. (1988). Inventaire commenté des amphibiens et reptiles du Maroc. Bulletin de l'Institut Scientifique, Rabat 12: 171 $-181$.

Metallinou, M. \& Crochet, P.-A. (2013). Nomenclature of African species of the genus Stenodactylus (Squamata: Gekkonidae). Zootaxa 3691: 365-376.

Metallinou, M.; Arnold, E.N.; Crochet, P.-A.; Geniez, P.; Brito, J.C.; Lymberakis, P.; BAHA El Din, S.; Sindaco, R.; Robinson, M. \& CARRANZA, S. (2012). Conquering the Sahara and Arabian deserts: systematics and biogeography of Stenodactylus geckos (Reptilia: Gekkonidae). BMC Evolutionary Biology 12: 258 .

Mittermeier, R.A; Robles Gil, M.; Hoffman, M.; Pilgrim, J.; Brooks, T.; Mittermeier, C.G.; Lamoreux, J. \& DA Fonseca, G.A.B. (2004). Hotspots Revisited. Earth's Biologically Richest and Most Endangered Terrestrial Ecoregions. University of Chicago Press, Chicago, Illinois, USA.

Myers, N.; Mittermeier, R.A.; Mittermeier, C.G.; DA Fonseca, G.A.B. \& Kent, J. (2000). Biodiversity hotspots for conservation pri- orities. Nature 403: 853-858.

Nagy, Z.T.; Lawson, R.; Joger, U. \& Wink, M. (2004). Molecular systematics of racers, whipsnakes and relatives (Reptilia: Colubridae) using mitochondrial and nuclear markers. Journal of Zoological Systematics and Evolutionary Research 42: 223-233.

Pabijan, M.; Crottini, A.; Reckwell, D.; IrisarRI, I.; Hauswaldt, J.S. \& Vences, M. (2012). A multigene species tree for Western Mediterranean painted frogs (Discoglossus). Molecular Phylogenetics and Evolution 64: 690696.

Perera, A.; Vasconcelos, R.; Harris, D.J.; Brown, R.P.; Carretero, M.A. \& PérezMellado, V. (2007). Complex patterns of morphological and mtDNA variation in Lacerta perspicillata (Reptilia; Lacertidae). Biological Journal of the Linnean Society 90: 479490.

PieH, A. (2006). New record of Eryx jaculus jaculus (Linnaeus, 1758) in Morocco. Herpetozoa 19: 93-94.

Pinho, C.; Harris, D.J. \& Ferrand, N. (2008). Non-equilibrium estimates of gene flow inferred from nuclear genealogies suggest that Iberian and North African wall lizards (Podarcis spp.) are an assemblage of incipient species. BMC Evolutionary Biology 8: 63.

Pleguezuelos, J.M.; Márquez, R. \& Lizana M. (2002). Atlas y Libro Rojo de los Anfibios y Reptiles de España. Dirección General de Conservación de la Naturaleza - Asociación Herpetológica Española, Madrid, Spain.

Real, R.; Pleguezuelos, J.M. \& Fahd, S. (1997). The distribution patterns of reptiles in the Riff region, northern Morocco. African Journal of Ecology 35: 312-325.

Recuero, E.; Iraola, A.; Rubio, X.; Machordom, A. \& García-París, M. (2007). Mitochondrial differentiation and biogeography of Hyla meridionalis (Anura: Hylidae): an unusual phylogeographical pattern. Journal of Biogeography 34: 1207-1219.

Recuero, E.; Canestrelli, D.; Vörös, J.; Szabó, K.; Poyarkov, N.A.; Arntzen, J.W.; Crnobr- 
NJa-Isailovic, J.; Kidov, A.A.; Cogălniceanu, D.; Caputo, F.P.; Nascetti, G. \& MarTínez-Solano, I. (2012). Multilocus species tree analyses resolve the radiation of the widespread Bufo bufo species group (Anura, Bufonidae). Molecular Phylogenetics and Evolution 62: 71-86.

Salvador, A. (1982): A Revision of the Lizards of the Genus Acanthodactylus (Sauria: Lacertidae). Series: Bonner Zoologische Monographien, vol. 16. Zoologisches Forschungsinstitut und Museum Alexander Koenig, Bonn, Germany.

Sauvage, C. (1961): Recherches Géobotaniques sur les Subéraies Marocaines. Series: Travaux de l'Institut Scientifique Chérifien. Série botanique, vol. 21. Société des Sciences Naturelles et Physiques du Maroc, Rabat, Morocco.

Schleich, H.H.; Kästle, W. \& Kabisch, K. (1996). Amphibians and Reptiles of North Africa. Koeltz, Koenigstein, Germany.

Sillero, N.; Celaya, L. \& Martín-Alfageme, S. (2005). Using geographical information systems (GIS) to make an atlas: a proposal to collect, store, map and analyse chorological data for herpetofauna. Revista Española de Herpetología 19: 87-101.

Soares, C.; Álvares, F.; Loureiro, A.; Sillero, N.; Arntzen, J.W. \& Brito, J.C. (2005). Atlas of the amphibians and reptiles of PenedaGerês National Park, Portugal. Herpetozoa 18: 155-170.

Sobrino, J.A. \& Raissouni N. (2000). Toward remote sensing methods for land cover dynamic monitoring: application to Morocco. International Journal of Remote Sensing 21: 353 -366 .

Steininger, F.F.; Rabeder, G. \& Rögl, F. (1985). Land mammal distribution in the Mediterranean Neogene: a consequence of geokinematic and climatic events, In D.J. Stanly, F.C. Wezel (eds.) The Geological Evolution of the Eastern Mediterranean. Springer, New York, USA, pp. 559-571.

Stoetzel, E.; El Agbani, M.A.; Qninba, A.;
Mouna, M.; Mataame, A.; El Brini, H. \& DenYs, C. (2010). Inventaire taxonomique préliminaire des petits vertébrés terrestres du Nord du Maroc. Bulletin de l'Institut Scientifique, Rabat, Section Sciences de la Vie 32: $17-24$.

VALDÉs, B. (2013). Checklist of the vascular plants collected during the fifth "Iter Mediterraneum" in Morocco, 8-27 June, 1992. Bocconea 26: 13-132.

Valdés, B.; Rejdali, M.; Achhal el Kadmiri, A.; Jury, J. L. \& Montserrat, J.M. (2002). Catalogue des Plantes Vasculaires du Nord $d u$ Maroc, Incluant des Clés d'Identification. Consejo Superior de Investigaciones Científicas, Madrid, Spain.

Velo-Antón, G.; Godinho, R.; Harris, D.J.; Santos, X.; Martínez-Freiría, F.; Fahd, S.; Larbes, S.; Pleguezuelos, J.M. \& Brito, J.C. (2012). Deep evolutionary lineages in a Western Mediterranean snake (Vipera latastei/monticola group) and high genetic structuring in Southern Iberian populations. Molecular Phylogenetics and Evolution 65: 965973.

Velo-Antón, G.; García-Cardenete, L.; Jiménez Cazalla, F. \& Martínez-Freiría, F. (2014). New record of Salamandra algira isolated on the north-western Tingitana peninsula, with some notes on the reproductive modes within the species. Boletin de la Asociación Herpetológica Española 25: 4650.

Vences, M.; de Pous, P.; Nicolas, V.; DíazRodríguez, J.; Donaire, D.; Hugemann, K.; Hauswaldt, J.S.; Аmat, F.; Barnestein, J.A.M.; Bogaerts, S.; Bouazza, A.; Carranza, S.; Galán, P.; González de la Vega, J.P.; Joger, U.; Lansari, A.; El Mouden, E.H.; Ohler, A.; Sanuy, D.; Slimani, T. \& Tejedo, M. (2014). New insights on phylogeography and distribution of painted frogs (Discoglossus) in northern Africa and the Iberian Peninsula. Amphibia-Reptilia 35: 305-320. WADE, E. (2001). Review of the false smooth snake genus Macroprotodon (Serpentes, 
Colubridae) in Algeria with a description of a new species. Bulletin of the Natural History Museum, Zoology Series 67: 85-107.

Wagner, P.; Melville, J.; Wilms, T.M. \& Schmitz, A. (2011). Opening a box of cryptic taxa - the first review of the North African desert lizards in the Trapelus mutabilis Merrem, 1820 complex (Squamata: Agamidae) with descriptions of new taxa. Zoological Journal of the Linnean Society 163: 884-912.

Wilms, T.M.; BöHme, W.; Wagner, P.; LutzmanN, N. \& Schmitz, A. (2007). On the phylogeny and taxonomy of the genus Uro- mastyx Merrem, 1820 (Reptilia: Squamata: Agamidae: Uromastycinae) - Resurrection of the genus Saara Gray, 1845. Bonner Zoologische Beiträge 56: 55-99.

Yus Ramos, R. \& Cabo Hernández, J.M. (1986). Guía de la Naturaleza de la Región de Melilla. Ayuntamiento de Melilla, Melilla, Spain.

Zangari, F.; Cimmaruta, R. \& Nascetti, G. (2006). Genetic relationships of the western Mediterranean painted frogs based on allozymes and mitochondrial markers: evolutionary and taxonomic inferences (Amphibia, Anura, Discoglossidae). Biological Journal of the Linnean Society 87: 515-536. 


\section{Appendix 1}

Distribution maps of the amphibian and reptiles species in northern Morocco. Solid black marks represent records from bibliographical sources. Grey marks with a central dot represent records from our own field observations.
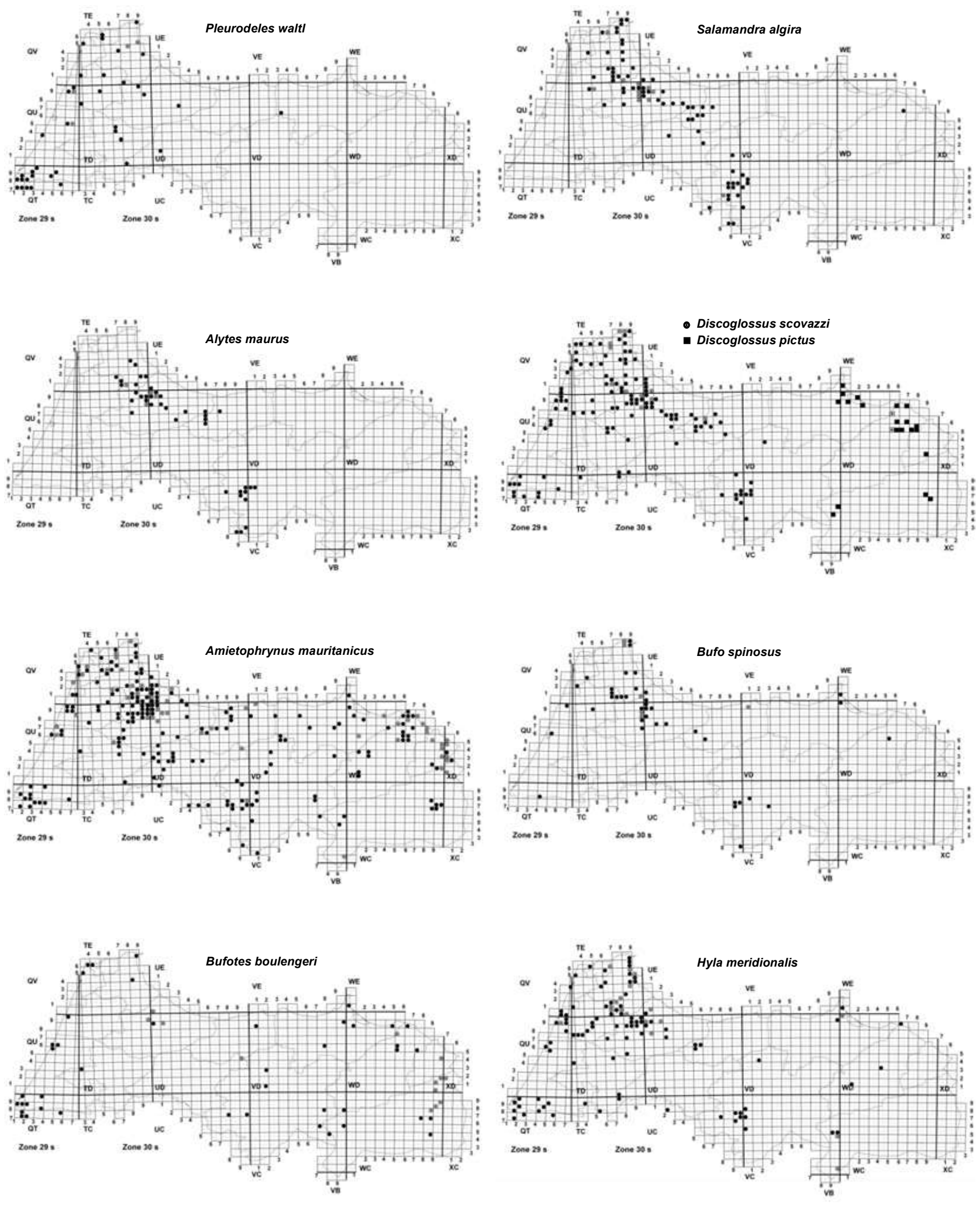

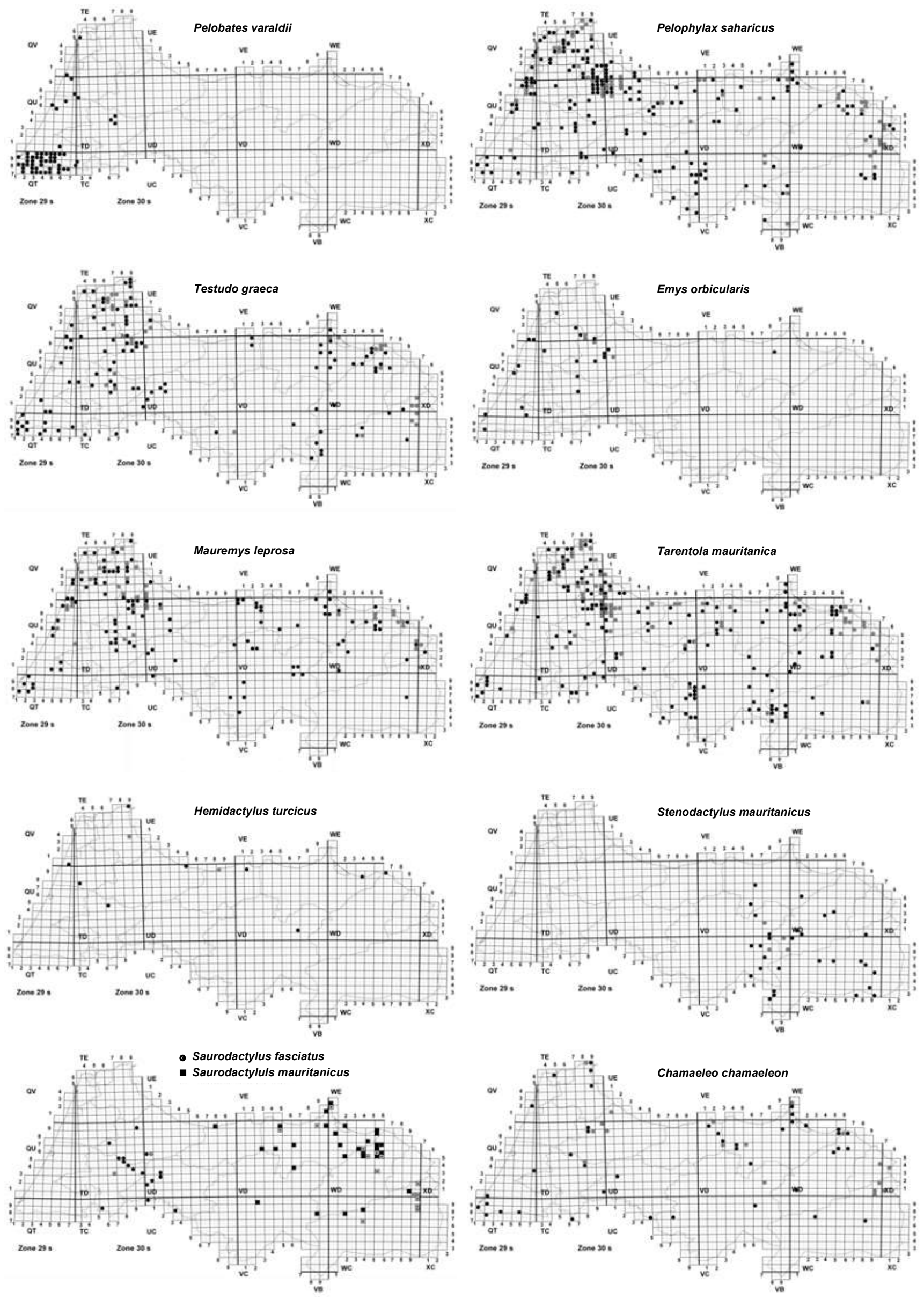

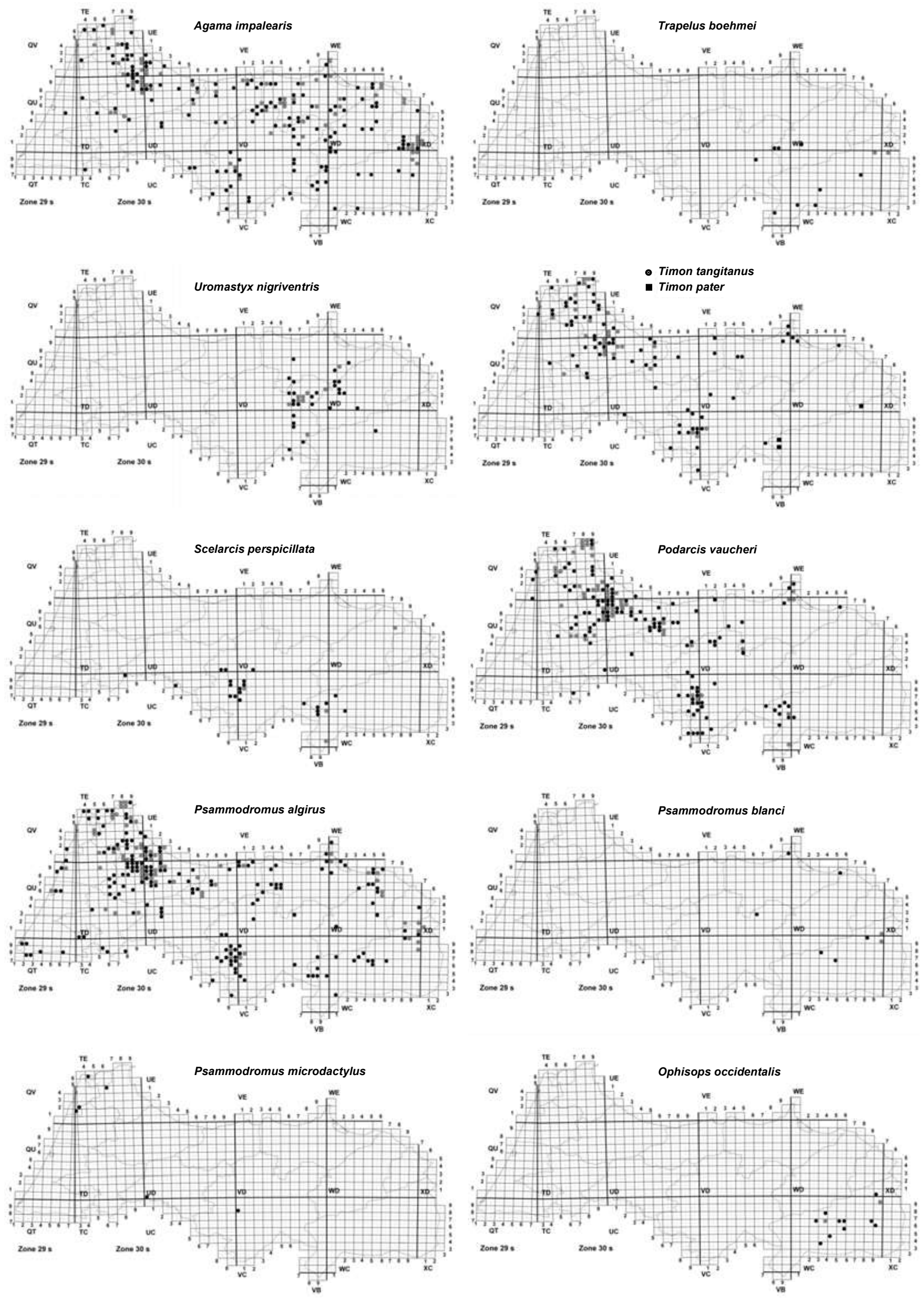

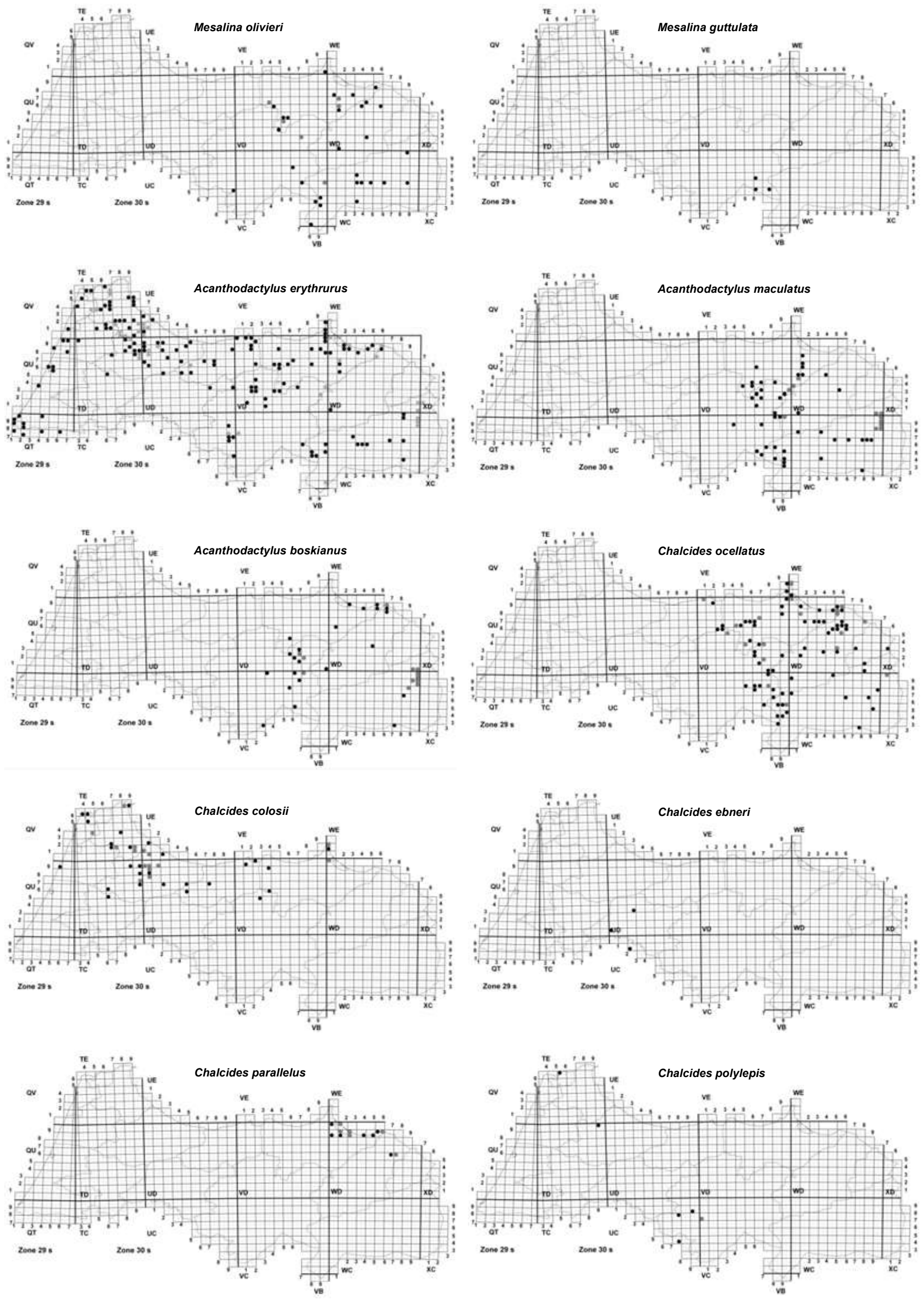

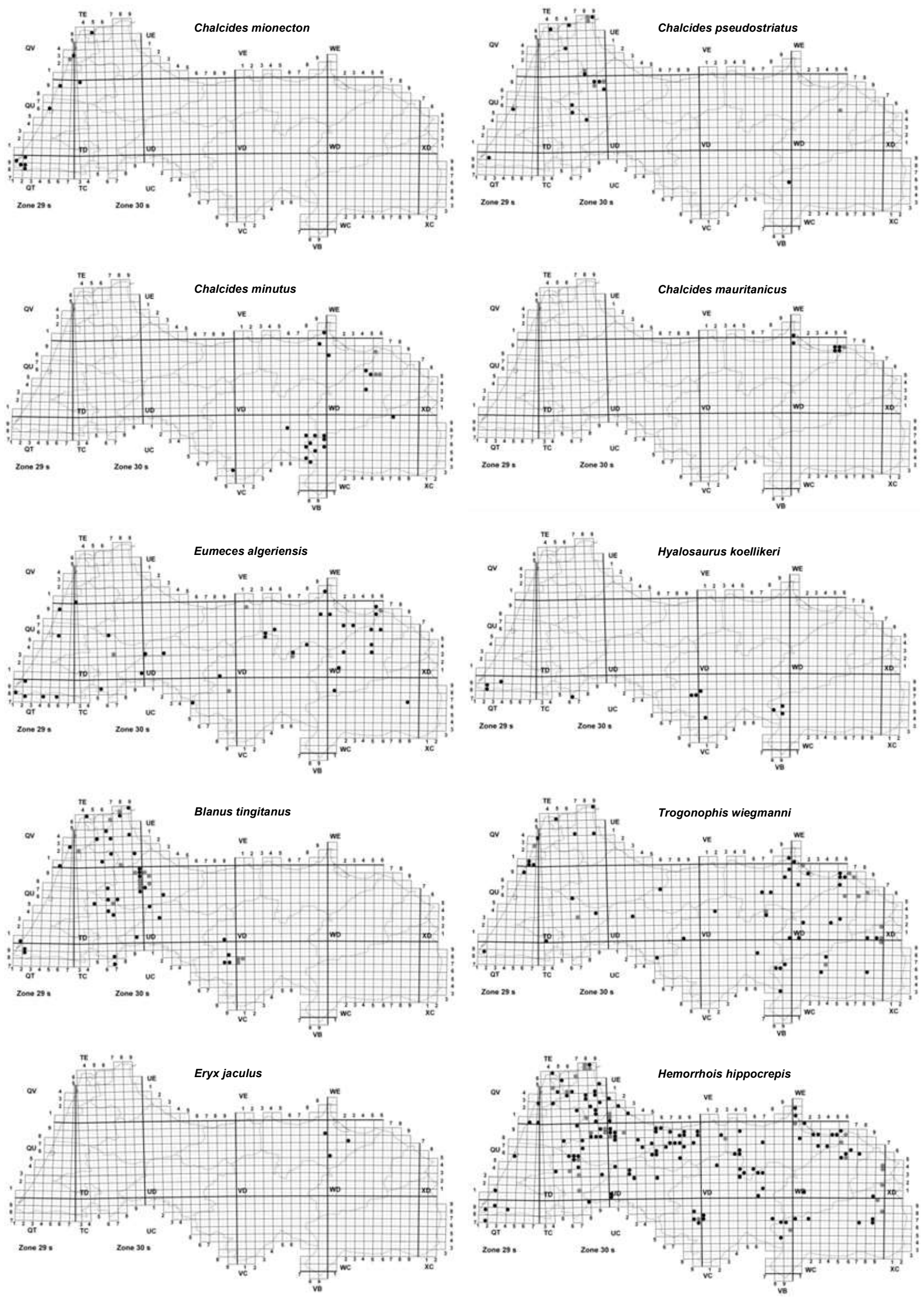

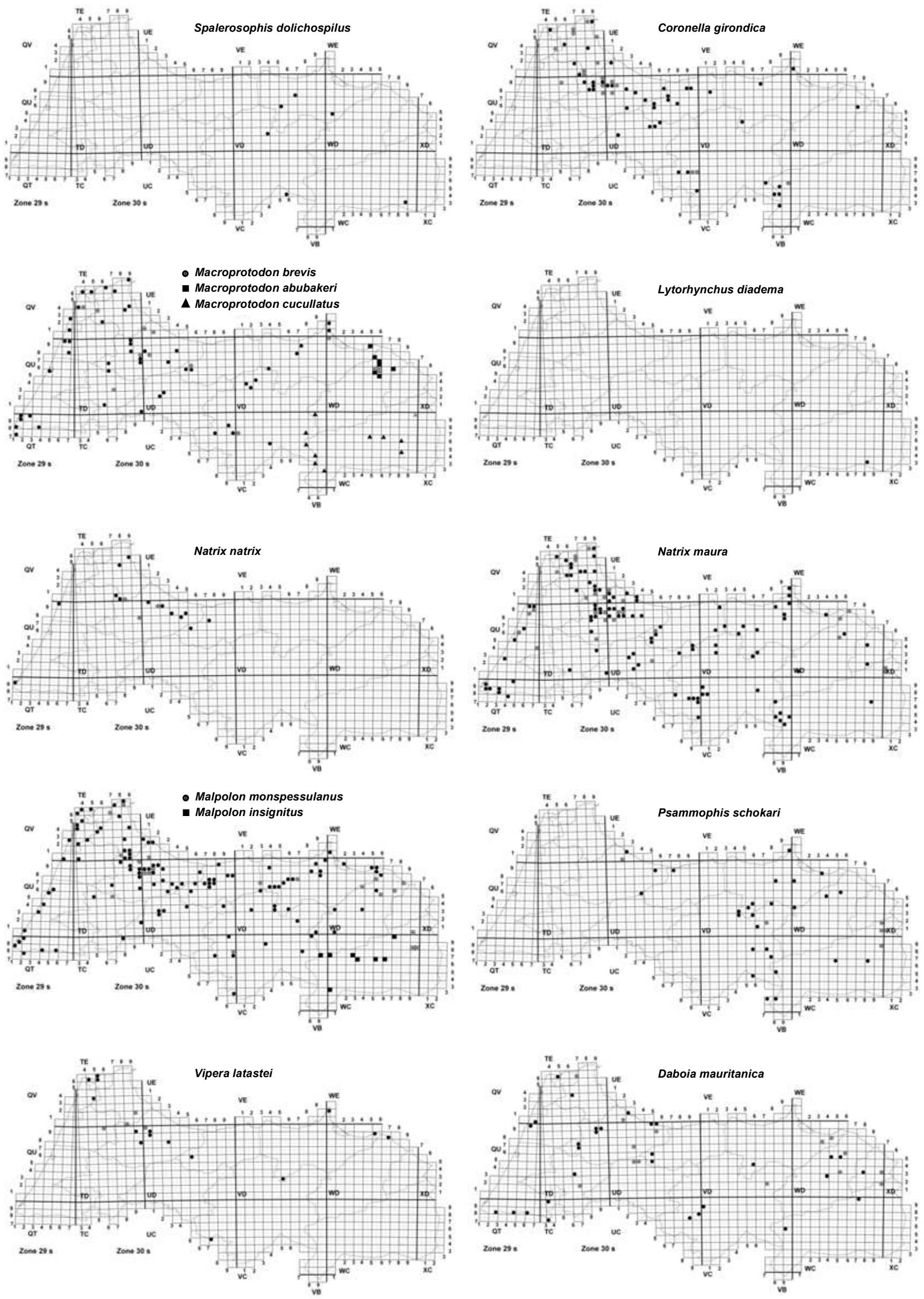